\title{
O VELHINHO DO CALOMBO
}

\section{Luiza Nana Yoshida}

RESUMO: Procura-se destacar algumas das particularidades do gênero setsuwa, que alcançou seu apogeu na época Kamakura (séculos XII-XIV), através do estudo de uma narrativa que apresenta características semelhantes ao mukashi banashi (histórias antigas). A figura do velhinho do calombo, cristalizada nos dias de hoje, como uma das mais populares do mukashi banashi, será revisitada e discutida, no presente trabalho, como uma personagem caracterizadora da narrativa setsuwa.

ABSTRACT: It is aimed to bring into evidence peculiarities of setsuwa, gender that had its apogee in Kamakura period $\left(12^{\text {th }} \sim 14^{\text {th }}\right.$ ce. $)$, through narrative study that presents similar characteristics of mukashi banashi (old tales). The figure of the old man with a wen, actually one of mukashi banashi most popular figures, will be revisited and reconsidered, in this article, like a setsuwa typical character.

PALAVRAS-CHAVE: narrativas setsuwa, literatura medieval, histórias antigas (mukashi banashi), velho-do-vizinho (tonarino okina).

KEYWORDS: setsuwa narratives, Medieval Literature, old tales (mukashi banashi), neighbor's old man (tonarino okina).

Dentre os gêneros que alcançaram o seu apogeu na época Kamakura (século XIIXIV), pode-se citar a narrativa setsuwa cuja origem remonta ao século IX. O termo setsuwa comporta diversas acepções, mas no presente trabalho refere-se às narrativas breves reunidas em coletâneas denominadas setsuwashû, especialmente numerosas no referido período. Nihon Ryôiki (século IX) é considerada a primeira delas e Konjaku Monogatarishû (século XII), a mais volumosa e a mais elaborada. Ambas são anteriores 
ao período áureo do setsuwa, mas de existência definitiva para as coletâneas que as sucederam.

Desde o seu surgimento, o homem busca perpetuar a sua presença e o seu tempo de diferentes maneiras, seja através de figuras desenhadas nas cavernas pré-históricas, seja através de transmissões orais ou de registros escritos. Nesse sentido, pode-se dizer que as narrativas setsuwa constituem legados de acontecimentos estabelecidos como ocorridos de fato num tempo passado e reunidas em um setsuwashî.

A obra Uji Shîi Monogatari, uma coletânea de narrativas setsuwa compilada no século XIII, apresenta a seguinte introdução':

Existe no mundo o que é conhecido como Narrativas do Alto Conselheiro Uji (Uji Dainagon Monogatari $)^{2}$. Alto Conselheiro, neste caso, refere-se a Takakuni ${ }^{3}$ Ele é neto do senhor de Nishinomiya ${ }^{4}$ e segundo filho do Alto Conselheiro Toshikata ${ }^{5}$. Com o avançar da idade, o calor lhe era cada mais insuportável, e retirado da vida pública, recolhia-se, do quinto ao oitavo mês, ao anexo denominado Nansenbô ${ }^{6}$, localizado no alto da montanha, ao sul do pavilhão Issai Kyôzô ${ }^{7}$ do templo Byôdôin ${ }^{8}$. Chamavam-Ihe Alto Conselheiro Uji. Com o rabicho ${ }^{9}$ preso desleixadamente e a aparência sem cuidados, refrescava-se na esteira estendida sobre o chão de madeira, e desfrutando o abanar da ventarola, interpelava os transeuntes que por lá passavam, independente de suas classes sociais; fazia com que lhe contassem uma narrativa passada, que ouvia deitado no interior do aposento e ia registrando numa grande folha de papel.

Encontram-se registrados fatos da Índia, da China bem como do Japão. Dentre eles, há fatos nobres, engraçados, medonhos, dignos de pena ou repugnantes, algumas invenções, fatos cômicos, enfim, uma miscelânea deles. (Grifo nosso.)

As pessoas apraziam-se em conhece-los. Perfaziam 14 brochuras $^{10}$. O original foi parar nas mãos do servidor imperial" Toshisada. Seu paradeiro atual é desconhecido. Posteriormente,

1. A tradução dos trechos foi feita, tendo como texto básico Uji Shûi Monogatari, organizado por Kobayashi Chishô, Coleção Completa de Literatura Clássica Japonesa (Nihon koten bungaku zenshû), vol. 28, Shôgakukan, Tóquio, 1973.

2. Uji Dainagon Monogatari - coletânea de narrativas setsıwa supostamente concluída na época Insei (1086-1185). Aparece citada em diversas obras e foi compilada provavelmente por Takakuni, mas a obra em si nunca foi encontrada.

3. Takakuni - refere-se a Minamoto no Takakuni (?-1177), conhecido como Uji Dainagon (Alto ConseIheiro Uji).

4. Senhor de Nishinomiya - refere-se a Minamoto no Takaakira (914-982), filho do imperador Daigo. Em 920, passa a condição de súdito e recebe o sobrenome Minamoto. Acusado de participar da Revolta de Anna (969), é nomeado Governador Geral e enviado para a distante região da atual região de Kyûshû de onde retorrna em 972. É conhecido como Nishinomiya Sadaijin.

5. Toshitaka - refere-se a Minamoto no Toshitaka, filho de Takaakira. Alcança o posto de Alto Conselheiro. Falece em 1027.

6. Nansenbô - residência dos monges, localizada no templo Byôdôin.

7. Issai Kyôzô - recinto onde se guarda o livro sagrado.

8. Byôdôin - templo localizado na região de Uji, em Kyoto. Originalmente residência de veraneio de Fujiwara no Michinaga, foi transformado em templo pelo seu filho Yorimichi, em 1052.

9. Rabicho - refere-se a motodori, tipo de penteado masculino adotado na época.

10. 14 brochuras - há outras edições com 15 brochuras.

11. Servidor imperial - refere-se a jijî, funcionário do Ministério dos Assuntos de Estado que trabalha junto ao imperador. 
pessoas entendidas acrescentaram suas contribuições, elevando o número de narrativas. Edições há que contêm fatos ocorridos em épocas posteriores às do Alto Conselheiro.

Nesse meio tempo, houve quem, mesmo agora, tenha inserido outras narrativas. Supõe-se que tenham reunido as narrativas que escaparam à coletânea do Alto Conselheiro, e outras relacionadas a fatos ocorridos posteriormente. A compilação é conhecida como Uji Shîino Monogatari ("narrativas compiladas em Uji”). Essa denominação encontra-se relacionada com o fato de "reunir o que restou em Uji". Ou ainda, considerando-se que jijû e shîi sejam sinônimos, denominou-se Uji Shâi Monogatari ("narrativas do servidor imperial de Uji”). Difícil é saber qual o correto. Não se tem certeza.

$\mathrm{Na}$ presente introdução podemos ver delineadas algumas das características essenciais do setsuwa como a tradição oral, o caráter coletivo de criação, a variedade de temas, entre outras. Pode-se dizer que o processo de criação de uma coletânea de setsuwa implica basicamente a existência de uma fonte (oral ou escrita) e de um compilador que organiza e registra as narrativas coletadas. As coletâneas não seguem uma estruturação uniforme, sendo algumas extremamente elaboradas, caso da obra Konjaku Monogatarishû cujas narrativas encontram-se classificadas por temas, outras como Uji Shûi Monogatari, cuja distribuição segue apenas a divisão em tomos e não obedece a uma classificação temática.

A narrativa monogatari, gênero representativo da época Heian (séculos VIII XII), alcança sua perfeição estrutural com a obra Genji Monogatari (Narrativas de Genji) escrita, no século XI, pela dama da Corte Murasaki Shikibu. Pode-se dizer que o monogatari constitui narrativa de caráter ficcional centrada no mundo da nobreza Heian e o setsuwa, uma narrativa de caráter tradicional daquilo que se conta pelo mundo. Os dois tipos de narrativas, segundo suas especificidades, caminham como gêneros complementares ${ }^{12}$, na medida em que o primeiro trata essencialmente do tema da nobreza de Heian, orientado pelo ideal literário do refinamento e da sensibilidade apurada, e o segundo caracteriza-se pela "quebra" desse ideal literário, privilegiando os aspectos não contemplados no monogatari, bem como ampliando o seu tema e, conseqüentemente o seu espaço de ação. A proposta do presente trabalho é, pois, a de destacar as peculiaridades do gênero setsuwa que encontrou um terreno bastante fértil para o seu desenvolvimento na época Kamakura.

\section{Os Velhinhos do Calombo}

Uji Shûi Monogatari é uma coletânea compilada no início da época Kamakura. Reúne 197 narrativas, distribuídas em 14 (ou 15) tomos, conforme a versão. A maioria delas (184 narrativas) inicia-se com uma das expressões padrões, Imawa mukashi ("agora é passado"), Koremo imawa mukashi ("isto também agora é passado"), Mukashi ("antigamente") ou Koremo mukashi ("isto também é passado"), expressões que

12. Cf. L. N. Yoshida, Narrativas setsuwa de Konjaku Monogatarishû - a Ruptura com o Refinamento Estético das Narrativas Clássicas da Época Heian. Tese de Doutorado, FFLCH-USP, 1994. 
remetem ao passado. Grande número de narrativas de Uji Shîi Monogatari pode ser encontrada em outras coletâneas do gênero, sendo pouco mais de 50 as narrativas reconhecidas como próprias de Uji Shûi Monogatari. Dentre elas incluem-se as narrativas que alcançaram nossos dias sob a forma de mukashi banashi (histórias antigas), ou mesmo de adaptações voltadas para o público infantil. A narrativa Sobre o calombo que foi retirado pelo ogro (narrativa 3 do tomo I), escolhida como objeto de análise e traduzida a seguir, faz parte desse tipo de narrativas que apresentam características semelhantes ao mukashi banashi, tais como a presença de expressões introdutória e final padronizadas ("Antigamente..." "Dizem que...”), caráter oral de transmissão, presença de elemento maravilhoso, entre outras.

\section{3/I Sobre o calombo que foi retirado pelo ogro}

Conta-se que também isto ocorreu no passado, havia um velho com um enorme calombo na face direita. Era do tamanho de uma laranja grande. Avesso à convivência com outras pessoas, ele se sustentava, cortando lenha, e como sempre fazia, certo dia, dirigiu-se à mata. Surpreendido por uma chuva torrencial, viu-se impedido de voltar para casa, sendo obrigado a abrigar-se dentro da mata. Não havia nenhum outro lenhador na redondeza. Foi tomado pelo pavor. Encontrando a toca de uma árvore, engatinhou para o seu interior e ali ficou agachado, sem nem mesmo conseguir pregar os olhos, quando ouviu ao longe, vozes de uma multidão que se aproximava, fazendo grande algazarra. Estando completamente só dentro da mata, a aproximação de pessoas causou-lhe a sensação de estar voltando à vida. Espiou o lado de fora da toca e deparou-se com seres de aparências diversas: os de corpo vermelho usavam sungas azuis e os de cor preta usavam sungas vermelhas; alguns tinham um só olho, outros não tinham boca. Eram seres monstruosos, indescritíveis que, reunidos em cerca de cem, acenderam um fogo brilhante como o sol e sentaram-se ao seu redor, justamente em frente à toca em que o velho se abrigara. Sentiu-se arrebatado pelo terror.

Um dos ogros, provavelmente o líder do grupo, sentara-se no lugar de honra. Incontável era o número de ogros que se sentaram enfileirados, ladeando-o. Impossível era descrever suas aparências. Os seus gestos, ao se divertirem, servindo saquê, eram exatamente iguais aos de um homem. Faziam a troca de taças repetidas vezes e o líder parecia estar especialmente embriagado. Um dos jovens ogros levantou-se do lugar destinado aos mais novos, colocou uma bandeja sobre a cabeça, e dizendo algo ininteligível, achegou-se lentamente diante do líder, sentado no lugar de honra, e passou a interpelá-lo insistentemente. A aparência do líder que, às gargalhadas, segurava a taça de saquê na mão esquerda, nada diferia da do homem. O jovem ogro terminou de dançar e retornou ao seu lugar. Os ogros dançaram um após o outro, começando pelos novatos. Alguns dançavam mal, outros, bem. O velho assistia a tudo atônito, quando disse o líder:

- A festa de hoje está especialmente ótima. Gostaria, porém, de assistir à uma dança especial.

Como se tivesse sido tomado por algo ou guiado pelas forças divinas, tais palavras despertaram no velho uma vontade enorme de dançar com eles. De qualquer forma, achou melhor não se precipitar. Levado, no entanto, pelo ritmo cativante dos ogros, pensou:

- Ah, deixa estar, vou sair e dançar. Se tiver que morrer, morrerei.

E o velho, com o chapéu ebosh $i^{13}$ pendido sobre o nariz, saiu dançando da toca, com o machado, seu instrumento de trabalho, enfiado na cintura, e postou-se diante do líder que permanecia sentado no lugar de honra. Os ogros sobressaltaram-se e se perguntavam, agitados:

13. Eboshi - tipo de chapéu sem abas utilizado na época. Originalmente era feito de tecido, mas passou-se a usar também papel japonês laqueado. 
- O que é isso?

O velho esticava-se, encolhia-se, dançava freneticamente, contorcendo o corpo, bradando: "Ei! Ei!" , e rodopiando pelo local. A começar pelo líder, os ogros ali reunidos apreciavam surpresos e perplexos.

Disse o líder:

- Há anos realizamos estas festas, mas nunca tinha visto alguém dançar tão bem. A partir de agora, velho, deverás participar, sem falta, de nossas festas.

Ao que respondeu o velho:

- Nem era necessário que me dissésseis, virei com prazer. Como desta vez fui pego de surpresa, até me esqueci dos passos finais da dança. Se a minha dança vos agradou, da próxima vez, dançarei com mais calma.

- Muito bem. Deverás vir, sem falta - disse o ogro líder.

- Este velho promete isso agora, mas temo que ele falte com a palavra e não apareça. Vós não achais melhor tomar alguma coisa como garantia? - disse o terceiro ogro sentado nos fundos.

- Certamente, certamente - concordou o ogro líder.

- Mas o que tomaríamos como penhor?

Enquanto todos discutiam com o que ficar, o líder tomou da palavra:

- Devemos ficar com o calombo que o velho traz no rosto. O calombo é o talismã da felicidade, e ele não irá querer perdê-lo.

Ao ouvi-lo, o velho suplicou:

- Ficai com os meus olhos ou mesmo o nariz, mas suplico-vos que não toqueis neste calombo. Não me parece lógico que me priveis, sem um bom motivo, de algo que carrego comigo há tanto tempo.

- O calombo lhe é muito caro. É isso o que devemos tomar-lhe - decidiu o líder.

Um dos ogros aproximou-se do velho e disse:

- Então vou retirá-lo. - Deu uma torcida e puxou o calombo que se desprendeu sem qualquer dor.

A seguir, o ogro reiterou:

- Tu não deves faltar ao nosso próximo encontro.

E como os pássaros começaram a cantar, anunciando o amanhecer, os ogros se foram.

O velho passou a mão pelo rosto e percebeu que não havia qualquer vestígio do calombo que carregara durante tantos anos. Atônito com o seu total desaparecimento - seu rosto estava liso - nem se lembrou de cortar a lenha e voltou para casa.

A sua idosa esposa perguntou-lhe: admirada:

- Mas o que foi que aconteceu? - e o velho narrou-lhe o acontecido. A velha comentou

- Que coisa espantosa.

O velho que morava no vizinho tinha um enorme calombo na face esquerda, e ao ver que o calombo do vizinho desaparecera, perguntou:

- Como foi que o calombo desapareceu? De onde é o médico que o retirou? Dize-me, por favor. Eu também quero me livrar deste calombo.

Respondeu-lhe o velho:

- Não foi retirado por nenhum médico. Aconteceu assim, assim e foi retirado pelos ogros.

Desejando também livrar-se do calombo, o vizinho quis saber de todos os detalhes, que foram relatados pormenorizadamente pelo velho.

$\mathrm{O}$ vizinho com calombo agiu exatamente como o velho fizera e permaneceu dentro da toca, quando ouviu a chegada dos ogros, conforme lhe tinha sido contado. 
Os ogros sentaram-se em círculo e divertiam-se, bebendo, até que o líder chamou pelo velho, dizendo:

- Como é, o velho está aí?

O velho, embora temeroso, saiu vagarosamente, balançando o corpo.

- O velho está aqui - responderam os ogros.

- Aproxima-te e dança imediatamente! - ordenou o líder.

O velho, no entanto, sem a habilidade do outro, dançou mal. Disse, então, o líder:

- Desta vez, dançaste mal. Dançaste muito mal! Devolvam-lhe o calombo que tomamos como garantia.

Lá dos fundos, surge, então, um ogro, que dizendo:

- Toma o calombo que retiramos como garantia - atira o calombo na face direita do velho que acaba ficando com calombos em ambas as faces.

Conta-se que não se deve cultivar a inveja.

\section{Antigamente, Havia um Velho}

Estruturalmente, a narrativa pode ser dividida da seguinte forma: $A-B-C\left(A^{\prime}\right.$ - B'-C'), onde a sequiência $A^{\prime}-B^{\prime}-C^{\prime}$ desenvolve resumidamente a mesma seqüência de acontecimentos do primeiro segmento, porém com protagonista diferente. Inicialmente, o velho que possui um calombo na face direita vai à mata cortar lenha $(A)$, dança diante dos ogros (B) e tem seu calombo retirado. Em seguida, o vizinho com um calombo na face esquerda busca repetir os mesmos passos do outro velho ( $\left.A^{\prime}\right)$, dança diante dos ogros (B') e acaba ficando com dois calombos, um em cada lado da face (C'). A narrativa fecha-se com uma frase de caráter moralizante: "Conta-se que não se deve cultivar a inveja"

Conforme colocado anteriormente, a narrativa setsuw' a refere-se a um fato que se conta como ocorrido no passado, e abre-se com expressões como imaw'a mukashi ("agora é passado"), mukashi ("antigamente"), koremo imawa mukashi ("isto também agora é passado"), ou ainda, koremo mukashi ("isto também é passado"), caso da narrativa do velhinho, estabelecendo uma imprecisão e distanciamento temporal. Trata-se de um recurso adotado já na obra Taketori Monogatari (Narrativa do Cortador de Bambu), do século IX, considerada a primeira do gênero monogatari. Este termo tem o sentido geral de "narrativa, relato", e é também a denominação dos gêneros narrativos da época Heian (794-1192) que se classificam em tsukuri monogatari (narrativa ficcional), uta monogatari (narrativas inspiradas em poemas) e rekishi monogatari (narrativas históricas). Quanto ao estabelecimento do tempo, a narrativa setsuw' a apresenta, portanto, características semelhantes aos monogatari da época Heian (Cf. obras como Taketori Monogatari ou Ise Monogatari.)

\section{O Velho e o Ogro}

O protagonista da presente narrativa é um velho com calombo na face direita que, na segunda parte da narrativa, é substituído pelo seu vizinho, um velho com calombo 
na face esquerda. São personagens sem nome, apenas caracterizadas pela peculiaridade física, faixa etária e ocupação. Trata-se, de certa maneira, de uma retomada do protagonista de Taketori Monogatari ${ }^{14}$, um velho cortador de bambu (cuja ocupação é também praticamente a mesma do velhinho do calombo, um lenhador). A referida narrativa abre-se da seguinte forma:

Agora é passado, havia uma pessoa conhecida como o velho cortador de bambu. Embrenhando-se na mata, colhia bambus que utilizava para diversos fins. Seu nome era Sanukino Miyatsuko. Havia dentre esses bambus, um, cuja base reluzia. Estranhando, aproximou-se para olhar, e o seu interior brilhava. Ao olhá-lo, viu uma pessoa minúscula sentada graciosamente.

A versão moderna de Taketori Monogatari é conhecida como Kaguyahime (A princesa Kaguya), e é formada pela estrutura fundamental de Taketori Monogatari, relatando a vida de Kaguyahime, desde o seu peculiar nascimento até o seu retorno à Lua de onde viera. Como marca de sua passagem pelo nosso mundo, Kaguyahime traz prosperidade ao casal de idosos que a cria, e no dia estabelecido, parte com a comitiva celestial, deixando os pais aos prantos e muitos corações partidos. Esta tradicional composição, casal de anciãos + (criança especial $)=($ prosperidade elou infortúnio $)$, perdura até os nossos dias, e pode ser encontrada, por exemplo, nas estórias antigas ou infantis, inclusive com variantes como dois casais de anciãos $+($ criança especial $)=$ (prosperidade elou infortúnio).

A narrativa Sobre o calombo que foi retirado pelo ogro apresenta a composição dois casais de anciãos + ogro = felicidade / desgraça, similar àquela utilizada em Taketori Monogatari. Mas esta, enquanto monogatari, apresenta uma sucessividade dramática, e aquela, na qualidade de setsuwa, caracteriza-se pela unidade dramática e uma proposta temática simplificada. Pode-se dizer que o setsıwashû é formado por uma sucessão de unidades dramáticas constituídas pelas narrativas setsuwa. Dessa forma, o setsuwa, pelas suas especificidades, diferencia-se, naturalmente, das várias modalidades do monogatari, mas pelo seu caráter narrativo, apresenta também características comuns, já aludidas anteriormente.

Dentre as várias modalidades do mukashi banashi existe aquela denominada tonarino jiji (velho-do-vizinho), sobre a qual Yanagita Kunio diz:

Trata-se de histórias que tentam produzir um efeito maior, comparando os extremos opostos, mostrando que uma pessoa afortunada de nascença ou uma pessoa bem intencionada, e por isso mesmo amada pelos deuses, não pode ser imitada por outra, por mais que esta tente fazê-lo's.

A narrativa Sobre o calombo que foi retirado pelo ogro apresenta similaridade com essa modalidade de mukashi banashi no que se refere à presença de dois vizinhos

14. Taketori Monogatari - obra do fim do século IX ou início do século X, é considerada a precurssora do gênero monogatari que alcança a sua perfeição literária com a obra Genji Monogatari, do século XI. Esta última será, portanto, a nossa referência, quando nos referimos ao gênero em questão.

15. K. Yanagita, "Momotarôno tanjô", Yanagita Kunioshû 8, Tóquio, Chikuma, 1980, pp. 16-17. 
idosos. A narrativa do tipo velho-do-vizinho entrou ao Japão via Coréia ${ }^{16}$, mas não se sabe precisar a data. Em Uji Shîi Monogatari, além da narrativa do velhinho do calombo, encontramos a narrativa Sobre a gratidão do pardal (narrativa 16, tomo III) que narra a história de uma anciã que cura um pardal ferido e recebe recompensas, e da sua vizinha que busca a mesma sorte, mas acaba encontrando a desgraça. Os mukashi banashi do tipo velho-do-vizinho são encontrados em todas as regiões do Japão, segundo etnólogos como Seki Keigo, e apresentam como protagonistas dois vizinhos idosos (ou idosas), o bom e o mau, e um final moralizante: o bom é recompensado e o mau, castigado. $\mathrm{Na}$ narrativa Sobre o calombo que foi retirado pelo ogro, no entanto, os protagonistas escapam ao caráter estereotipado do "bom velhinho" ou do "mau velhinho" sendo diferenciados apenas pela maior ou menor habilidade em dançar, fato que vai definir o destino de cada um deles. "Avesso à convivência com outras pessoas" por possuir um calombo na face direita, o destino do velhinho começa a tomar novo rumo, quando ele se "mistura" aos ogros, seres também "avessos à convivência com os homens". e apresenta a sua dança, que segundo o etnólogo Yanagita Kunio, originariamente, "era um meio de alegrar as divindades e fazer os pedidos" 17

Cabe colocar que a dança e a figura do ancião mantêm uma relação bastante próxima, desde os tempos antigos. Atualmente, o vocábulo okina é utilizado com o sentido de "ancião", mas, segundo Orikuchi Shinobu ${ }^{18}$, existe a acepção artística okina mai (bailado do ancião) que foi difundida pela arte do sarugaku ("macaquice"), originária do sangaku ("divertimentos variados"), teatro circense nascido na Ásia Central, constituído de acrobacia, mágica e mímica cômica, e que chegou ao Japão, através da China, por volta do século VIII. A denominação sarugaku vem substituir sangaku, a partir do momento em que a arte passa a privilegiar e aperfeiçoar essencialmente a parte da mímica, relegando a acrobacia e a mágica a simples acessórios ${ }^{19}$

Pode-se dizer que Uji Shûi Monogatari trabalha com o duplo sentido de okina: o "ancião artista" e o ancião com o sentido literal de "pessoa idosa" Assim, o velhinho com o calombo na face direita representa um ancião naturalmente voltado para o okina mai, o que explica o seu sucesso diante dos ogros, e seu vizinho com o calombo na face esquerda representa o mero ancião, que não possui o dom do okina mai, sendo, portanto, incapaz de agradar e entreter os ogros. Destaque-se o fato de que o "ancião artista" possui diversos atributos que o caraterizam como tal: além do talento natural para a dança, o velho com o calombo na face direita é incapaz de refrear sua paixão pela "arte da dança" e, se preciso, dispõe-se a trocar a própria vida pela dança, bem como realiza uma encenação com o objetivo explícito de se ver livre do calombo. O velho do vizinho,

16. E. Nakajima, "Uji Shûi Monogatari: onini kobu toraruru kotonitsuite", Atomi Gakuen Joshidaigakı Kiyô, vol. 4, Tóquio, março/1971, p. 29.

17. K. Yanagita, "Odorino imato mukashi". Yanagita Kunioshî-Dainanakan, Tóquio, Chikuma, 1980, p. 423.

18. S. Orikuchi, "Okinano hassei", Orikuchi Shinobu zenshû - Dainikan, Tóquio, Chûô Kôronsha, 1965, p. 371.

19. Sobre sarugaku cf., S. M. Giroux, "O sarugaku e a Formação do Nô", Zeami: Cena e Pensamento Nô, São Paulo, Perspectiva/Aliança Cultural Brasil-Japão,1991, pp. 3-21. 
que busca imitar os passos do primeiro, não obtém êxito, pois sua dança não possui coreografia, apenas movimentos desajeitados. Pelos movimentos descritos, "O velho esticava-se, encolhia-se, dançava freneticamente, contorcendo o corpo, bradando: 'Ei! Ei!' e rodopiando pelo local", a dança apreciada pelos ogros, não possui o caráter ritualístico e solene da "dança aristocrática" praticada em Heiankyô, antiga capital, pela nobreza que ali residia. Transposta para um ambiente diverso, no caso, o interior da mata, a dança adquire um caráter laicizante e lúdico, mas não menos artístico. Cabe retomarmos a colocação feita anteriormente sobre a mútua complementaridade dos gêneros monogatari e setsıwa. A "dança aristocrática" que é caracterizada por movimentos formalizados, indumentária própria e acompanhamento musical, e apresentada em espaços restritos como o palácio imperial ou as residências dos nobres, faz parte do mundo literário das narrativas monogatari. A narrativa sobre o velho do calombo registra a existência da dança que foge às regras vigentes e é praticada além dos muros desses recintos fechados.

O ogro ou oni é também uma figura constantemente presente na literatura clássica japonesa. Sua figura se confunde, ora com divindades (do bem ou do mal), ora com monstros, e alcança nossos dias como um ser de aparência humana, porém, assustadora, trajado com uma espécie de sunga de pele de tigre. A figura do ogro da narrativa de $U j i$ Shîi Monogatari segue, em linhas gerais, o padrão encontrado em Heian, concebido pela nobreza da época. Conforme estudo anterior ${ }^{20}$, na coletânea do fim da época Heian, Konjaku Monogatarishû, o ogro possui o seguinte perfil:

a) o ogro pode ser dividido em dois grupos: o ligado ao mundo do Budismo, quando aparece como demônio do inferno budista, e o ligado ao mundo secular, que possui capacidade de transformação;

b) sua aparição ocorre na Capital ou suas imediações, principalmente em habitações ou templos abandonados, pontes ou montanhas, depois do entardecer;

c) o ogro surge como ser maléfico que persegue e até mata o homem.

A aparência física do ogro pode ser também variada, e em Konjaku Monogatarishû, na narrativa 7 do tomo XX Sobre o fato da Imperatriz Somedono ter sido violentada por um tengu, encontra-se a seguinte descrição, que coincide com a figura consagrada do ogro:

Era uma figura seminua, com o cabelo escorrido como o de uma criança. Tinha mais de dois metros de altura e a pele escura como que pintada de laca. Os olhos eram enormes e assustadores, lembrando duas tigelas metálicas; na gigantesca boca aberta viam-se dentes afiados tais como espadas, onde se destacavam as presas. Vestia-se com uma sunga vermelha e, na cintura, trazia um maço.

Conforme descrição apresentada anteriormente, os ogros de Uji Shûi Monogatari possuem também uma aparência assustadora, mas diferentemente da ação dos ogros de Konjaku Monogatarish $\hat{u}$, que muitas vezes resultam na morte do homem, aqueles causam,

20. L. N. Yoshida, “A Figura do oni em Konjaku Monogatari”, Estudos Japoneses 13, São Paulo, Centro de Estudos Japoneses da Universidade de São Paulo, 1993. 
no máximo, um grande susto. Pode-se dizer que casos de contato tão próximo e de uma interação homem / ogro vistos na narrativa do velhinho do calombo são raros. Os ogros assemelhavam-se a seres imaginários, pois muitas vezes não são vistos, apenas pressentidos e extremamente temidos, sendo a eles atribuídos uma série de acontecimentos horripilantes, como as mortes ocorridas de forma cruel ou inexplicável. Nesse aspecto, os ogros de Uji Shûi Monogatari, apesar de suas figuras assustadoras, não constituem, em nenhum momento, qualquer ameaça ao velhinho. Seu objetivo consiste em buscar um bom entretenimento. São ogros cujo comportamento e gestos não diferem daqueles dos homens, conforme enfatizado na própria narrativa.

\section{Ao Anoitecer, no Interior da Mata}

O enfoque de espaços até então inexplorados pela literatura vigente constitui também uma das peculiaridades da narrativa setsuwa. As narrativas monogatari refletem o período de estabelecimento de uma literatura mais autenticamente japonesa, com o desenvolvimento do silabário japonês, por volta do século IX, tendo como tema central a sociedade aristocrática de Heiankyô. Assim, a narrativa monogatari da época Heian busca retratar a realidade da sociedade aristocrática, orientada essencialmente pelo ideal literário do refinamento e da sensibilidade que refletem o estilo de vida da nobreza.

A narrativa setsuwa, por seu lado, retrata a sociedade aristocrática sob um prisma diverso, e busca também alcançar a totalidade do mundo circunstante, visto que para ela inexistem fronteiras, indo aportar nos mais diversos espaços, do mais próximo ao mais longínquo, do cotidiano ao imaginário.

O meio da mata, onde se desenrola a ação da presente narrativa, pode ser também considerado uma retomada do espaço de Taketori Monogatari, tal qual se deu com o protagonista okina. O meio da mata ou a montanha é o espaço freqüentemente relacionado ao "outro mundo" e estabelecido como próprio para o aparecimento do ogro ${ }^{21}$ ou de outros seres que não o homem, tendo, portanto a função de criar uma "atmosfera” propícia ao desenvolvimento da ação. Esta concepção vem enfatizada, ainda, na narrativa, pela presença da toca da árvore. Ao adentrar na toca para se proteger da chuva, o velho do calombo passa simbolicamente para um espaço diverso do cotidiano, onde o inexplicável torna-se possível. É no meio da mata que o cortador de bambu encontra a minúscula Kaguyahime, no interior de um bambu reluzente, em Taketori Monogatari, e é no meio da mata que o velhinho do calombo encontra-se com o grupo de ogros, cativa-os com a sua dança e tem o seu calombo retirado. E tudo acontece entre o entardecer e o amanhecer, enquanto o "mundo cotidiano" dorme: "E como os pássaros começaram a cantar, anunciando o amanhecer" os ogros se vão, levando o calombo.

21. Cf. Akiko Baba, Onino kenkyû, Tóquio, San’ichi Shobô, 1975, p. 111. 


\section{O Velho do Vizinho}

A parte final da narrativa, conforme colocado anteriormente, repete a estruturação inicial. O desenrolar dos acontecimentos é o mesmo (a nível narrativo, os acontecimentos são resumidos e não, narrados), mas o protagonista e o desfecho são como segmentos espelhados da estruturação inicial. Trata-se agora de um velhinho com calombo na face esquerda (como se fosse a imagem do primeiro velhinho refletida no espelho) e que não possui qualquer afinidade com o okina mai. Assim, o desfecho vai constituir também um inverso, na medida em que o calombo é devolvido (em vez de ser retirado), contrariando a expectativa do velhinho que buscava livrar-se dele, e acaba por ficar com dois deles.

Diferentemente dos mukashi banashi do tipo velho-do-vizinho, em que a existência do velho e de seu vizinho justifica-se, na medida em que surgem sempre como personagens contrastantes a nível moral (bom/mau), na narrativa de Uji Shîi Monogatari o destino dos dois velhinhos independe do caráter moral, e vem a ser definido pelo fato de ter ou não habilidade na arte da dança. Entretanto, o remate, "Conta-se que não se deve cultivar a inveja”, encerra uma proposição de fundo moral. Segundo Masuda Katsumi, o velho do vizinho assemelha-se ao modokiyaku, a personagem tipo bufão que faz imitações cômicas do protagonista, e a malograda imitação não encerra uma oposição de fundo moral, senão que se constitui num entretenimento ${ }^{22}$. Ainda, segundo Komine Kazuaki, a inexistência dessa contraposição de caráter moral entre os dois velhos acaba por dar maior relevância à colocação final moralizante, na medida em que isso transcende a narrativa e vai atingir diretamente o leitor/ouvinte. O velho do vizinho é visto, então, em primeira instância, como objeto de riso, mas a presença dessa moral leva o leitor/ ouvinte a reconhecê-lo como seu alter ego ou a sua "sombra"23. Já Miki Sumito busca estabelecer a narrativa do velhinho do calombo como um exemplo da lógica e da ilógica com as quais o homem se depara durante a sua existência. Por trás dessa proposição moralizante lançada de maneira despretensiosa pelo autor de Uji Shûi Monogatari, haveria essa intencionalidade implícita ${ }^{24}$

De fato, essa colocação final (que pode ser encontrada também na narrativa do tipo velho-do-vizinho 6 / III Sobre a gratidão do pardal), soa-nos inesperada e destoante. Mas é também justamente essa quebra que liberta os dois velhinhos do estereótipo "bom" ou "mau", atribuindo-lhes maior individualidade.

Diante da dificuldade de encontrar uma definição capaz de abarcar o significado global da narrativa setsuwa, procuramos definir o seu perfil, através do estudo da narrativa Sobre o calombo que foi retirado pelo ogro, destacando as principais características que a compõem. A narrativa setsıwa, conforme sua própria denominação é uma "narrativa" "transmitida como ocorrida de fato [...], transcrita tal qual ou com

22. Apud K. Komine, “Uji Shûi Monogatarito mukashi banashi”, Setsuwato shisô.shakai, Tóquio, Ôfûsha, 1987, p. 14.

23. Idem, ibidem.

24. S. Miki, "Uji Shûi Monogatari”, Chûseino bungaku, Tóquio, Yûhikaku, 1976, p. 88. 
algum adorno literário" 25 Ou conforme Nagano Jôichi ${ }^{26}$, "A literatura setsuwa é a transformação do fato verídico ou que se conta como verídico em fato literário [...], uma narrativa que pode ser contada de um só fôlego [...]" A narrativa setsuwa encontrase, portanto, estabelecida como um fato do passado que se difundiu através da tradição oral (ou escrita), e foi registrada em coletâneas, denominadas setsuwashû, compiladas em grande número na época Kamakura. Pode-se dizer que a época Kamakura foi propícia para o surgimento do setsuwashî, devido a uma série de fatores. Foi na época Kamakura, por exemplo, que a nobreza cedeu espaço à classe guerreira (bushi), ocasionando uma intensa efervescência e transformação social, política e cultural. Além do centro político (civil) vigente em Heiankyô (localizado na região oeste), há o estabelecimento de um centro político militar em Kamakura (na região leste do Japão). Desse modo, a época Kamakura é marcada por uma maior mobilidade das pessoas (o ir e vir entre os dois centros políticos, bem como entre as várias províncias originárias dos grupos bushi), até então concentradas em Heiankyô, proporcionando uma difusão e diversificação cultural. Não se pode deixar de registrar também que foi na época Kamakura que se desenvolveram as seitas budistas de cunho pragmático, em contraste com o Budismo esotérico ou dogmático dominante entre a nobreza, que buscavam uma aproximação com a população. Segundo Imanari Genshô, as origens do setsuwatsû têm estreita relação com o fervor dos monges budistas em divulgar os caminhos para a salvação ou os poderes miraculosos do Budismo, e assim, quanto mais remota a época, maior a produção de coletâneas de cunho budista, verificando-se, com o decorrer do tempo, a predominância das coletâneas compostas por narrativas setsuwa tanto budistas quanto seculares $^{27}$ Uji Shîi Monogatari pode ser considerada uma coletânea em que os temas seculares têm existência marcante, tornando tênue a coloração budista. Afastando-se bastante do propósito original pode-se dizer que Uji Shûi Monogatari constitui-se também numa coletânea de tipos humanos, antecipando, de certa forma, o estudo psicológico de personagens, ainda que a nível superficial, conforme atesta a narrativa do velhinho do calombo.

\section{Bibliografia}

BABA, Akiko. Onino kenkyû (Pesquisa sobre o ogro). Tóquio, San “ichi Shobô, 1992.

CHIGIRı, Kôsai. Onino kenkyû (Pesquisa sobre o ogro). Tóquio, Tairiku Shobô, 1978.

IKEBE, Minoru. Setsuwano honshitsuto kenkyû (A essência e a pesquisa do setsuwa). Tóquio, Shintensha, 1992.

INADA, Toshinori et al. Chûsei bungakuno sekai (O Mundo da Literatura Medieval). Quioto, Sekai Shisôsha, 1984.

25. K. Mabuchi, "Setsuwa bungakuo kenkyûsuru hitono tameni”, Kokubungaku 3, Tóquio, Gakutôsha, pp. 79 e 80.

26. J. Nagano, Setsuw'a bungaku jiten, Tóquio, Tôkyôdô, 1969, p. 7.

27. G. Imanari, "Setsuwato setsuwa bungaku”, Kenkyû shiryô Nihon koten bungaku 3, Tóquio, Meiji Shoin, 1984, pp. 1-6. 
KomINE, Kazuaki. "Uji Shûi Monogatarito mukashi banashi - tonarino okinakeio yomu” ("Uji Shûi Monogatari e as histórias antigas - a leitura das do tipo velho-do-vizinho). In SETSUWA DENSHÔ GAKKAI. Setsuwato Shisô. Shakai (Narrativas setsuwa-Pensamento/Sociedade). Tóquio, Ôfûsha, 1987, pp. 9-23.

MıKI, Sumito et al. Kenkyû shiryô Nihon koten bungaku (Material de pesquisa sobre Literatura Clássica Japonesa). Tóquio, Meiji Shoin, 1984.

NaKaJima, Etsuji. "Uji Shûi Monogatari: onini kobu toraruru kotonitsuite" ("Uji Shûi Monogatari: sobre o calombo que foi retirado pelo ogro"). Atomi Gakuen Joshidaigaku Kiyô, vol. 4. Tóquio, Atomi Gakuen Joshi Daigaku, março/71, pp. 29-33.

NisHIO, Kôichi. Chûsei setsuwa bungakuron (Estudo sobre a Literatura setsuwa Medieval). Tóquio, Hanawa Shobô, 1964.

ORIKUCHI, Shinobu. "Onino hassei" ("O surgimento do ogro"). Orikuchi Shinobu Zenshû Dainikan (Obras completas de Orikuchi Shinobu, vol. 2). Tóquio, Chûô Kôronsha, 1965, pp. 371-415.

YanAGITA, Kunio. "Odorino imato mukashi" ("O presente e o passado da dança"). In Yanagita Kunioshû - Dainanakan (Obras de Yanagita Kunio, vol. 7). Tóquio, Chikuma Shobô, 1980, pp. 403-437.

YANAGITA, Kunio. "Yamano jinsei" (“A vida da montanha”). Yanagita Kunioshû - Daiyonkan (Obras completas de Yanagita Kunio, vol. 4). Tóquio, Chikuma Shobô, 1962, 6ª edição, pp. 57-171. 